\title{
MHRT expression during remote ischemic preconditioning in patients with coronary artery disease
}

\author{
M. Khetsuriani ${ }^{1}$, N. O. Ioffe ${ }^{2}$, T. I. Drevytska ${ }^{1}$, V. O. Niekrasova ${ }^{3}$, V. E. Dosenkoํ․ \\ ${ }^{1}$ O. O. Bogomoletz Institute of Physiology, NAS of Ukraine \\ 4, Akademika Bogomoltsa Str., Kyiv, Ukraine, 01004 \\ 2 Amosov National Institute of Cardiovascular Surgery, National Academy of Medical Sciences of Ukraine \\ 6, Mykoly Amosova Str., Kyiv, Ukraine, 03038 \\ ${ }^{3}$ Educational and Scientific Center "Institute of Biology and Medicine", Taras Shevchenko National University of Kyiv \\ 64/13, Volodymyrska Str., Kyiv, Ukraine, 01601 \\ michael.khetsuriani@gmail.com
}

\begin{abstract}
Aim. This study aimed to access the effect of remote ischemic preconditioning (RIPC) on hemodynamic parameters and expression of lncRNA MHRT in patients with coronary artery disease during isolated coronary artery bypass graft surgery. Methods. The hemodynamic parameters of 29 patients with sham and RIPC procedure were analyzed. RIPC was modulated by three cycles of blocking blood flow in the arm for 5 minutes followed by restoring it for another 5 minutes. Expression of MHRT was measured in myocardial tissue and plasma by real-time polymerase chain reaction. Results. Hemodynamic parameters of patients in the RIPC-group had higher $(\mathrm{p}<0.05)$ values of cardiac index, systolic blood pressure, diastolic blood pressure, stroke volume index compared to the sham group. Systemic vascular resistance index decreased in RIPC-group. The expression level of MHRT in the myocardium was 2.5 times lower than in the sham group $(\mathrm{p}<0.05)$. MHRT expression in plasma fall[s] significantly, by more [than]15 times, $(p<0.0001)$ in the RIPC-group. Conclusions. A decrease in MHRT expression can be a consequence of the protective effect of RIPC and can be used as a cardiac biomarker.
\end{abstract}

Ke y w o r d s: long noncoding RNA, ischemic preconditioning, MHRT, coronary artery disease, coronary artery bypass grafting

\section{Introduction}

Remote ischemic preconditioning (RIPC) is a short episode of ischemia-reperfusion of a certain organ that may be protective for distant tissues or organs. Protective effects of RIPC are explained by releasing biochemical messengers that have protective properties. In 1993

(C) 2021 M. Khetsuriani et al.; Published by the Institute of Molecular Biology and Genetics, NAS of Ukraine on behalf of Biopolymers and Cell. This is an Open Access article distributed under the terms of the Creative Commons Attribution License (http://creativecommons.org/licenses/by/4.0/), which permits unrestricted reuse, distribution, and reproduction in any medium, provided the original work is properly cited 
McClanahan et al. for the first time demonstrated the protective effect of RIPC on myocardium [1]. They found that short periods of ischemia followed by reperfusion in kidney protected myocardium from prolonged ischemia and reduced the infarct size. Skeletal limb preconditioning also demonstrates the beneficial effect for myocardium and endothelial tissues in patients [2]. There are a few studies showing that limb RIPC reduces not only cardiac, but neuronal injury after prolonged ischemia or cardiac arrest [3-6].

It has been reported that RIPC could be a potential protective measure for perioperative complication [7,8]. RIPC may have [a] beneficial effect on [the] coronary artery bypass grafting $(\mathrm{CABG})$ surgery in patients with coronary artery disease. It can be shown by the changes in cardiodynamic parameters during surgery as well as by the determination of a number of molecules. Over the past two decades considerable attention has been paid to the study of the noncoding transcriptome in particular long noncoding RNAs (lncRNAs).

LncRNAs are considered to be non-coding ribonucleic acids larger than 200 nucleotides. The biogenesis of lncRNAs is similar to that of [the] messenger RNAs (mRNAs). Transcription of lncRNAs like mRNA is provided by promoter elements, transcription factors, and certain modifications of histone proteins [9]. Like mRNAs, IncRNAs are spliced, 5'-capped and 3'-polyadenylated to form mature forms of molecules [10]. To date about 70 thousand[s] long non-coding RNAs have been identified. These molecules perform a variety of functions in different tissues and organs, including the cardiovascular system. The indirect evidences have been obtained that $\operatorname{lncRNAs}$ regulate cardiomyocyte metabolism, hypertrophy, differentiation and proliferation [11]. The expression profiles of lncRNAs in plasma have also shown the possibility of using them as potential biomarkers [12].

The lncRNA MHRT (Myosin Heavy Chain Associated RNA Transcripts) originates from MYH7 loci. It is a cardiospecific lncRNA that may play a significant role in myocardial protection. It was demonstrated that mouse MHRT inhibits cardiac hypertrophy and failure [13]. It has also been reported that rat MHRT protects cardiomyocytes from oxidative stress [14]. Interestingly, human MHRT is upregulated in patients with acute myocardial infarction (AMI). It could be used as a biomarker for early diagnosis of myocardial injury [14]. In this study we evaluate [the] plasma and myocardial MHRT levels in patients with coronary artery disease undergoing RIPC before CABG surgery. We suggest that the change in the expression of IncRNA MHRT in this case may be an additional indicator for the RIPC effect on cardiovascular system.

\section{Materials and Methods}

\section{Patients}

Patients of the Amosov National Institute of Cardiovascular Surgery NAMS of Ukraine with coronary heart disease participated in this study. The present study was approved by the Biomedical Ethics Commission of the Amosov National Institute of Cardiovascular Surgery. All patients were subjected to isolated offpump CABG surgery.

Hemodynamic parameters were assessed using the method of impedance cardiography 
(ICG). The ICG technique makes it possible to determine the following hemodynamic parameters: stroke volume index (SVI), cardiac output (CO), cardiac output index (COI), systemic vascular resistance (SVRI).

$\mathrm{CO}$ is the volume of blood that the heart pumps in one minute. It consists of the stroke volume (SV) multiplied by the heart rate (HR). Cardiac output divided by body surface area is the cardiac index (CI).

The data on hemodynamic parameters from 29 patients were used to examine the effect of ischemic preconditioning. An experimental group includes 13 patients who were subjected to RIPC before surgery. A control group includes 16 patients who were surged without prior RIPC.

Myocardial biopsies and plasma of 14 patients were used to assess the expression of MHRT. 6 patients got sham-procedure (applying a cuff to the right forearm without RIPC) and 8 got RIPC before surgery. The average age of patients in sham-group was $60.8 \pm 3.9$ while in experimental group it was $60.1 \pm 5.8$. According to the NYHA Classification all patients were classified as Class II or Class III.

Evaluation of perioperative risks with the EUROSCORE 2 scale was $1.92 \pm 0.31 \%$ and $1.83 \pm 0.56 \%$ for patients in sham- and RIPC groups respectively. There was no significant difference among patients of both groups in clinical and laboratory parameters before surgery. The average ejection fraction of left ventricle was $56.9 \pm 5.4 \%$ in control group and $58.1 \pm 4.9 \%$ in experimental group. The average number of distal anastomosis was $3.1 \pm 0.8$ and $3.0 \pm 0.6$ in control and experimental groups respectively.

\section{Ischemic preconditioning}

The RIPC procedure was performed on patients before surgery by applying a cuff to the right arm. The cuff was inflated to a pressure of $200 \mathrm{~mm} \mathrm{Hg}$ and left for 5 minutes. This was followed by a reperfusion step for 5 minutes. Periods of ischemia and reperfusion for $5 \mathrm{~min}$ utes were repeated three times [15]. In the sham group the cuff was applied to the right forearm but RIPC was not performed.

\section{Coronary artery bypass graft surgery}

Coronary artery bypass graft surgery on working heart was performed in several steps. The first step was preparing patients to the operation: setting monitoring, catheterization of peripheral vein and artery for measuring invasive blood pressure. The second step was induction and intubation. Patients got intravenously propofol in dose $2-4 \mathrm{mg} / \mathrm{kg}$ and fentanyl in dose $10-15 \mathrm{ug} / \mathrm{kg} / \mathrm{hr}$. To relax trachea for intubation, rocuronium bromide (Esmeron) was used in dose $0.6-1 \mathrm{mg} / \mathrm{kg}$. Artificial ventilation was performed in normal ventilation state with oxygen concentration $30 \%-60 \%$. Ventilation parameters were monitored by blood gas test. The third step was formation of distal anastomosis. The forth step was completion of surgery.

\section{Collection of samples}

Vein blood was collected from all 14 patients before RIPC (control samples). From 6 patients vein blood was collected 20 minutes after sham procedure (sham group) and from 8 patients -20 minutes after RIPC procedure. Additionally myocardium tissue was collected during the surgery. Blood was centrifuged 15 minutes on $1000 \mathrm{rpm}$ to separate blood frac- 
tions. MHRT expression was measured in myocardium as well as in plasma.

\section{RNA extraction}

To extract RNA from samples we used guanidine isothiocyanate-phenol-chloroform extraction protocol with Trizol reagent (Invitrogen). Extracted RNA was diluted 50 times in $\mathrm{dH} 2 \mathrm{O}$ and its concentration was measured by spectrophotometer (Nano-Drop ND1000). Isolation of total RNA from blood plasma was performed with addition of miR-39 in concentration of $1 \mathrm{fM} / 1 \mu \mathrm{l}$ (miR Neasy Serum/Plasma Spike-In Control, Syn-cel-miR-39 miRNA, Lot No. 227926630, product of United States).

\section{Reverse transcription}

Reverse transcription was performed in two steps. Initially $6 \mu \mathrm{l}$ of total RNA were mixed with $1 \mu 1$ of Random Hexamer Primer and 5 $\mu \mathrm{l}$ of $\mathrm{dH} 2 \mathrm{O}$. Probes were incubated for $5 \mathrm{~min}-$ utes at $70{ }^{\circ} \mathrm{C}$ in thermal cycler Gene Amp ${ }^{\circledR}$ PCR System 2700, Applied Biosystems (USA). Subsequently, $2 \mu \mathrm{l}$ of dNTP (x10), $4 \mu \mathrm{l}$ of Buffer RT, $0.5 \mu 1$ of RiboLock RNAse inhibitor and $0.9 \mu \mathrm{l}$ of Revert Aid RT were added to probes. Probes were incubated for 60 minutes at $42{ }^{\circ} \mathrm{C}$, then 10 minutes at $70{ }^{\circ} \mathrm{C}$. Reverse transcription of plasma RNA was performed using specific loop primers for cel-miR-39 miRNA.

\section{Quantitative real-time PCR}

We used thermal cycler 7500 Fast Real Time PCR made by Applied Biosystems (USA) and 96-well plate for qPCR. The used mix included $5 \mu$ of SybrGreen max, $2 \mu 1$ of cDNA, $0.08 \mu \mathrm{l}$ of specific primers for human MHRT, $0.2 \mu \mathrm{l}$ of Rox (1:9) and $2.72 \mu \mathrm{l}$ of $\mathrm{H}_{2} \mathrm{O}$. The final reaction volume was $10 \mu \mathrm{l}$. DNA denaturation was performed at $95{ }^{\circ} \mathrm{C}$ for $15 \mathrm{sec}$. Probes annealing and elongation occurred at $60{ }^{\circ} \mathrm{C}$ for 1 minute. Number of cycles was set at 50 .

\section{Statistical analysis}

Wilcoxon signed-rank test was used to analyze hemodynamic parameters. One-way ANOVA test was used to analyze the changes in expression of MHRT. Statistical significance was indicated when $\mathrm{p}<0.05$.

\section{Results and Discussion}

\section{Hemodynamic parameters}

Hemodynamic parameters were recorded during all stages of the operation. At the stage of induction the hemodynamic parameters did not differ significantly in both groups. Significant changes in the hemodynamic parameters were observed at the stage of formation of distal anastomoses (Table 1).

As indicated in Table 1, CI (cardiac index) of patients in the RIPC group was higher by $19 \%$ compared with patients in the sham group. SBP (systolic blood pressure) and DBP (diastolic blood pressure) were significantly higher in RIPC patients. The SVI index (stroke volume index) in patients of the RIPC group was higher by $14 \%$ and the rate of SVRI (systemic vascular resistance index) was significantly lower in RIPC group. No significant difference in HR (heart rate) and CVP (central venous pressure) was observed in patients of two groups. Based on hemodynamic parameters we can conclude that [the] patients in RIPC group were more hemodynamically stable. 
Table 1. Hemodynamic parameters at the stage of distal anastomoses formation

\begin{tabular}{l|l|l}
\hline \multicolumn{1}{c|}{ Parameter } & \multicolumn{1}{c|}{$\begin{array}{c}\text { RIPC group } \\
\mathrm{N}=13, \mathrm{M} \pm \mathrm{SD}\end{array}$} & $\begin{array}{c}\text { SHAM group } \\
\mathrm{N}=16, \mathrm{M} \pm \mathrm{SD}\end{array}$ \\
\hline HR $(\mathrm{bpm})$ & $82.31 \pm 3.17$ & $84.25 \pm 5.45$ \\
\hline $\mathrm{SBP}(\mathrm{mmHg})$ & $98.54 \pm 4.35^{*}$ & $91.65 \pm 5.7$ \\
\hline $\mathrm{DBP}(\mathrm{mmHg})$ & $58.15 \pm 5.4^{*}$ & $52.15 \pm 3.3$ \\
\hline $\mathrm{CVP}(\mathrm{mmWg})$ & $62.1 \pm 5.4$ & $59.3 \pm 9.8$ \\
\hline $\mathrm{CI}\left(\mathrm{L} / \mathrm{min} / \mathrm{m}^{2}\right)$ & $3.12 \pm 0.85^{*}$ & $2.42 \pm 1.12$ \\
\hline $\mathrm{SVI}\left(\mathrm{ml} / \mathrm{m}^{2}\right)$ & $43.34 \pm 2.26^{*}$ & $35.50 \pm 5.45$ \\
\hline SVRI $\left(\mathrm{dyn} \cdot \mathrm{s} / \mathrm{cm}^{5} / \mathrm{m}^{2}\right)$ & $2367.3 \pm 213.5^{*}$ & $2638.5 \pm 494.2$ \\
\hline$* \mathrm{p}<0.05$ & \multicolumn{3}{|l}{}
\end{tabular}

\section{MHRT expression in myocardium}

There are several studies indicating that $\ln$ cRNA MHRT protects heart from hypertrophy and oxidative stress $[13,14]$. Other studies report that MHRT could be a novel biomarker related to heart hypertrophy and heart failure $[16,17]$. These studies have shown that increasing expression of MHRT indicates the development of a pathological process. On the other hand, Hang CT et al. have shown that the development of heart hypertrophy in mice is associated with the activation of Brg1-HdacParp chromatin repressor complex that inhibits

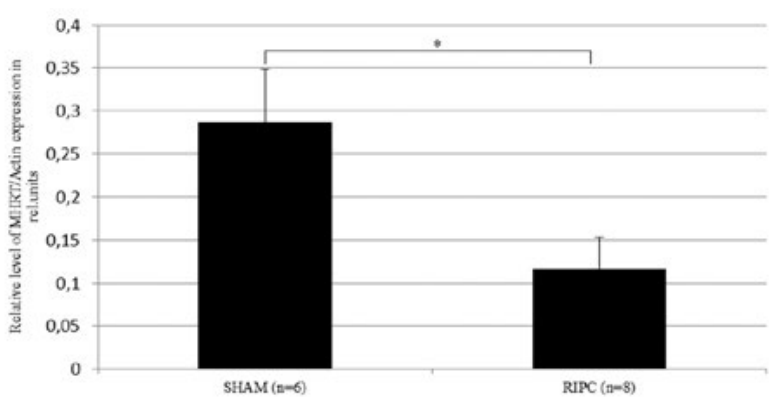

Fig. 1a. Level of myocardium MHRT expression in sham and RIPC group.

$* \mathrm{p}<0.05$ the expression of MHRT resulting in a heart pathology [18].

The molecular mechanisms of the protective effect of MHRT are unknown. Moreover, no studies have yet been performed to evaluate the MHRT expression in human myocardium. Our study shows that the level of MHRT expression in myocardium of RIPC patients is about 2.5 times lower than in sham group (Fig. 1). This is another indirect confirmation of the protective effect of RIPC. We hypothesize that MHRT downregulation in RIPC patients could be explained by the oxidative stress reduction. It is well known that RIPC protects from oxidative stress [19]. Yildirim $F$ et al. have shown the reduction of free oxygen radicals in blood samples of the patients undergoing RIPC before coronary artery bypass graft surgery [20].

\section{MHRT expression in plasma}

Interestingly, propofol used for anesthesia also has antioxidant properties and reduces the oxidative stress $[21,22]$. The evaluation of lncRNAs expression in blood plasma of our patients makes it possible to assess the control

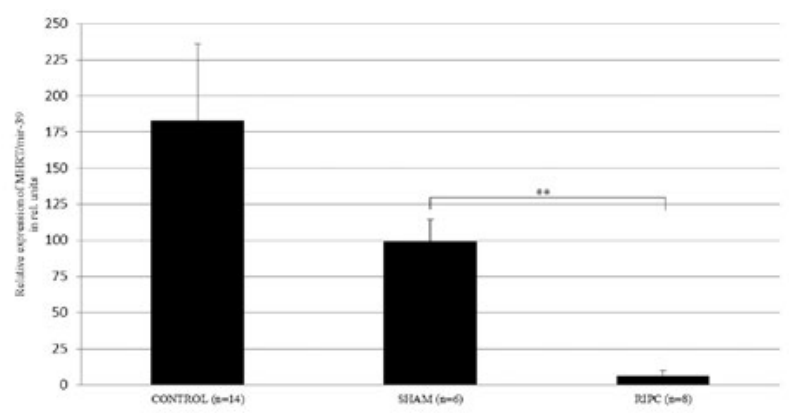

Fig. 2. Level of plasma MHRT expression before and after RIPC.

$* * \mathrm{p}<0.0001$ 
level of MHRT expression (before anesthesia and RIPC) as well as after RIPC.

Blood samples were taken from 14 patients prior to RIPC for evaluation of MHRT expression. Among these 14 patients 6 underwent sham procedure and $8-$ RIPC. As shown in Figure 2 the level of MHRT expression in sham group is almost half as much as control level. However, this is not significant differences $(p>0.05)$. We hypothesize that a possible drop in the level of MHRT expression in the sham group may be caused by the antioxidant effect of propofol [21, 22]. At the same time in the RIPC patients the level of MHRT expression is more than 15 times lower than in the sham group $(p<0.0001)$.

These changes of MHRT expression in myocardium and plasma suggest that MHRT can be secreted into plasma in exosomes. LncRNAs can enter the blood stream encapsulated in exosomes and extracellular vesicles [23]. We assume that a decrease in MHRT expression in myocardium may be associated with the regulation of RNA expression. However, a decrease in MHRT level by more than 15 times in plasma after RIPC probably indicates an inhibition of exosome secretion.

\section{Conclusions}

We conclude that RIPC improves hemodynamic parameters in patients undergoing CABG surgery. RIPC decreases MHRT level in myocardium about 2.5 times and more than 15 times in blood plasma. Such a drastic decrease of MHRT level in the blood plasma during RIPC once again indirectly confirms the potential use of MHRT as a cardiac biomarker.

\section{REFERENCES}

1. McClanahan T, Nao B, Wolke L, Martin B, Metz T, Gallagher $K$. Brief renal occlusion and reperfusion reduces myocardial infarct size in rabbits. FASEB J. 1993;7:A118.

2. Kharbanda RK, Mortensen UM, White PA, Kristiansen SB, Schmidt MR, Hoschtitzky JA, Vogel M, Sorensen K, Redington AN, MacAllister R. Transient limb ischemia induces remote ischemic preconditioning in vivo. Circulation. 2002;106(23):2881-3.

3. Kakimoto $M$, Kawaguchi $M$, Sakamoto T, Inoue $S$, Furuya H, Nakamura M, Konishi N. Evaluation of rapid ischemic preconditioning in a rabbit model of spinal cord ischemia. Anesthesiology. 2003; 99(5):1112-7.

4. Dave KR, Saul I, Prado R, Busto R, Perez-Pinzon MA. Remote organ ischemic preconditioning protect brain from ischemic damage following asphyxial cardiac arrest. Neurosci Lett. 2006;404(1-2):170-5.

5. Jin RL, Li WB, Li QJ, Zhang M, Xian XH, Sun XC, Zhao $H G$, Qi J. The role of extracellular signalregulated kinases in the neuroprotection of limb ischemic preconditioning. Neurosci Res. 2006; 55(1):65-73.

6. Steiger HJ, Hänggi D. Ischaemic preconditioning of the brain, mechanisms and applications. Acta Neurochir (Wien). 2007;149(1):1-10.

7. Cheung MM, Kharbanda RK, Konstantinov IE, Shimizu M, Frndova H, Li J, Holtby HM, Cox PN, Smallhorn JF, Van Arsdell GS, Redington AN. Randomized controlled trial of the effects of remote ischemic preconditioning on children undergoing cardiac surgery: first clinical application in humans. $J$ Am Coll Cardiol. 2006 ;47(11):2277-82.

8. Hausenloy DJ, Mwamure PK, Venugopal V, Harris J, Barnard M, Grundy E, Ashley E, Vichare $S$, Di Salvo C, Kolvekar S, Hayward M, Keogh B, MacAllister RJ, Yellon DM. Effect of remote ischaemic preconditioning on myocardial injury in patients undergoing coronary artery bypass graft surgery: a randomised controlled trial. Lancet. 2007;370(9587):575-9.

9. Amort T, Soulière MF, Wille A, Jia XY, Fiegl H, Wörle $H$, et al. Long non-coding RNAs as targets 
for cytosine methylation. RNA Biol. 2013; 10(6):1003-8.

10. Yoon JH, Abdelmohsen K, Gorospe M. Posttranscriptional gene regulation by long noncoding RNA. J Mol Biol. 2013;425(19):3723-30.

11. Grote P, Wittler L, Hendrix D, Koch F, Währisch S, Beisaw A, et al. The tissue-specific lncRNA Fendrr is an essential regulator of heart and body wall development in the mouse. Dev Cell. 2013;24(2): 206-14.

12. Vausort $M$, Wagner DR, Devaux $Y$. Long noncoding RNAs in patients with acute myocardial infarction. Circ Res. 2014;115(7):668-77.

13. Han P, Li W, Lin CH, Yang J, Shang C, Nuernberg ST, Jin KK, Xu W, Lin CY, Lin CJ, Xiong $Y$, Chien H, Zhou B, Ashley E, Bernstein D, Chen PS, Chen HV, Quertermous T, Chang CP. A long noncoding RNA protects the heart from pathological hypertrophy. Nature. 2014;514(7520):102-6.

14. Zhang J, Gao C, Meng M, Tang H. Long Noncoding RNA MHRT Protects Cardiomyocytes against H2O2-Induced Apoptosis. Biomol Ther (Seoul). 2016;24(1):19-24.

15. Hoole SP, Heck PM, Sharples L, Khan SN, Duehmke R, Densem CG, Clarke SC, Shapiro LM, Schofield PM, O'Sullivan M, Dutka DP. Cardiac Remote Ischemic Preconditioning in Coronary Stenting (CRISP Stent) Study: a prospective, randomized control trial. Circulation. 2009;119(6):820-7.

16. Kontaraki JE, Marketou ME, Kochiadakis GE, Maragkoudakis S, Konstantinou J, Vardas PE, Parthenakis FI. The long non-coding RNAs MHRT, FENDRR and CARMEN, their expression levels in peripheral blood mono-nuclear cells in patients with essential hypertension and their relation to heart hypertrophy. Clin Exp Pharmacol Physiol. 2018;45(11):1213-7.

17. Xuan L, Sun L, Zhang Y, Huang Y, Hou Y, Li Q, Guo Y, Feng B, Cui L, Wang X, Wang Z, Tian Y, $Y u$, Wang $S, X u$, Zhang $M, D u Z$, Lu Y, Yang BF. Circulating long non-coding RNAs NRON and MHRT as novel predictive biomarkers of heart failure. J Cell Mol Med. 2017;21(9):1803-14.

18. Hang CT, Yang J, Han P, Cheng HL, Shang C, Ashley E, Zhou B, Chang CP. Chromatin regulation by $\operatorname{Brg} 1$ underlies heart muscle development and disease. Nature. 2010;466(7302):62-7.

19. Motomura A, Shimizu M, Kato A, Motomura K, Yamamichi A, Koyama H, Ohka F, Nishikawa T, Nishimura Y, Hara M, Fukuda T, Bando Y, Nishimura T, Wakabayashi T, Natsume A. Remote ischemic preconditioning protects human neural stem cells from oxidative stress. Apoptosis. 2017;22(11):1353-61.

20. Yildirim F, Iskesen I, Kurdal AT, Ozturk T, Taneli F, Gozukara C, Ozbakkaloglu A. Is "Attenuation of Oxidative Stress" Helpful to Understand the Mechanism of Remote Ischemic Preconditioning in Cardiac Surgery? J Cardiothorac Vasc Anesth. 2016; 30(1):134-40.

21. Allaouchiche B, Debon R, Goudable J, Chassard D, Duflo $F$. Oxidative stress status during exposure to propofol, sevoflurane and desflurane. Anesth Analg. 2001;93(4):981-5.

22. Liu XR, Cao L, Li T, Chen LL, Yu YY, Huang WJ, Liu L, Tan $X Q$. Propofol attenuates $\mathrm{H} 2 \mathrm{O} 2$-induced oxidative stress and apoptosis via the mitochondriaand ER-medicated pathways in neonatal rat cardiomyocytes. Apoptosis. 2017;22(5):639-46.

23. Li Q, Shao Y, Zhang X, Zheng T, Miao M, Qin L, Wang B, Ye G, Xiao B, Guo J. Plasma long noncoding RNA protected by exosomes as a potential stable biomarker for gastric cancer. Tumour Biol. 2015;36(3):2007-12.

\section{Експресія MHRT при віддаленому ішемічному прекондиціонуванні у паціснтів з ішемічною хворобою серця}

М. Хецуріані, Н. О. Іоффе, Т. І. Древицька, В. О. Нєкрасова, В. Є. Досенко

Мета. Метою дослідження була оцінка впливу віддаленго ішемічного прекондиціонування (ВІПК) на гемодинамічні показники і експресію днкРНК MHRT у пацієнтів з ішемічною хворобою серця під час операції ізольованого аортокоронарного шунтування. Методи. Аналізувалися дані гемодинамічних показників від 29 пацієнтів з контрольної (К) і ВІПК -групи. ВІПК проводилося у три цикли перекривання кровотоку в плечі на 5 хвилин $з$ подальшим його відновленням на 5 хвилин. Експресію MHRT визначався у міо- 
карді й лейкоцитах за допомогою полімеразної ланцюгової реакції в реальному часі. Результати. У пацієнтів ВІПК-групи підвищувалися $(\mathrm{p}<0,05)$ значення серцевого індексу, систолічного артеріального тиску, діастолічного артеріального тиску, ударного індекс у порівнянні з К-групою. Навпаки, індекс загального переферичного судинного опору знижувався в групі BIПК. Рівень експресії MHRT в міокарді був в 2,5 рази нижче, ніж в К-групі $(\mathrm{p}<0,05)$. У плазмі рівень МHRT значно, більше ніж у 15 разів, $(\mathrm{p}<0,0001)$ падав у BIПК-групі. Висновки. Зниження експресії MHRT може бути наслідком захисного ефекту ВІПК і йомовірно може використовуватися в якості серцевого біомаркеру.

К л юч о в і с л о в а: довгі некодуючі РНК, ішемічне прекондиціонування, МHRT, ішемічна хвороба серця, аортокоронарне шунтування.

\section{Экспрессия MHRT при дистанционном ишемическом прекондиционировании у пациентов с ишемической болезнью сердца}

М. Хецуриани, Н. А. Иоффе, Т. И. Древицкая, В. О. Некрасова, В. Е. Досенко

Цель. Целью исследования была оценка влияния дистанционного ишемического прекондиционирования (ДИПК) на гемодинамические параметры и экспрессию днкРНК MHRT у пациентов с ишемической болезнью сердца во время операции изолированного аортокоронарного шунтирования. Методы. Анализировались данные гемодинамических параметров 29 пациентов из контрольной (К) и ДИПК-групп. ДИПК проходило в три цикла перекрывания кровотока в плече на 5 минут с последующим его восстановлением на 5 минут. Экспрессию MHRT измеряли в миокарде и плазме с помощью полимеразной цепной реакции в реальном времени. Результаты. У пациентов в ДИПК-группе повышались $(p<0,05)$ значения сердечного индекса, систолического артериального давления, диастолического артериального давления, ударного индекса по сравнению с К-группой. Напротив, индекс системного сосудистого сопротивления снижался в группе ДИПК. Уровень экспрессии MHRT в миокарде был в 2,5 раза ниже, чем в К-группе $(\mathrm{p}<0,05)$. В плазме уровень МНRT значительно, более чем в 15 раз, (p <0,0001) падал в ДИПК-группе. Выводы. Снижение экспрессии MHRT может быть следствием защитного эффекта ДИПК и может использоваться в качестве биомаркера сердечно-сосудистых заболеваний.

Кл юч е в ы е с л о в а: длинная некодирующая РНК, ишемическое прекондиционирование, MHRT, ишемическая болезнь сердца, аортокоронарное шунтирование.

Received 04.04.2021 